\title{
Pengembangan Karakter-Cerdas Mahasiswa melalui Infusi dalam Pembelajaran
}

\author{
Dr. Alizamar, M.Pd., Kons \\ Universitas Negeri Padang
}

\begin{abstract}
Mahasiswa sebagai sasaran pembelajaran di perguruan tinggi menghadapi berbagai tantangan yang cukup signifikan yang mempengaruhi aspek-aspek kehidupannya. Penyiapan mahasiswa sebagai salah satu ujung tombak dalam mewujudkan cita-cita nasional dalam menghadapi tantangan tersebut merupakan hal yang sangat krusial. Kondisi-kondisi anti karakter-cerdas sebagai salah satu tantangan tersebut selayaknyalah mendapat perhatian penuh dari pelaksana pembelajaran di perguruan tinggi. Sehingga perlu adanya upaya yang masif dalam mengembangkan nilai-nilai karakter-cerdas mahasiswa, salah satunya adalah dalam proses pembelajaran. Pendidikan karakter-cerdas yang dilakukan dalam proses pembelajaran akan cukup efektif dengan menerapkan strategi transformatif BMB3 dan pendekatan infusi, yakni dengan memasukkan/menginfusikan nilai karakter-cerdas ke dalam materi/konten pembelajaran. Hal ini dimaksudkan agar mahasiswa secara nyata dapat mengantisipasisegala bentuk tantangan yang ada di kehidupan pribadi maupun masyarakat dengan mengimplementasikannilai-nilai karakter-cerdas.
\end{abstract}

Kata kunci :Pendidikan, karakter-cerdas, infusi, pembelajaran

Published by Panitia International Counseling Seminar, $13-14^{\text {th }}$ Maret 2014

\section{PENDAHULUAN}

Pendidikan tinggi sebagai penyelenggara pembelajaran dalam bentuk proses interaksi mahasiswadengan dosen dan sumber belajar pada suatu lingkungan belajar mempunyai tujuan untuk mengembangkan segenap potensi sasaran ajarnya(Undang-undang Republik Indonesia Nomor 12 Tahun 2012). Sasaran rencana tersebut pada dasarnya telah tertuang dalam tujuan sistem pendidikan nasional yakni terwujudnya sistem pendidikan sebagai suatu pranata sosial yang kuat dan berwibawa sehingga pada akhirnya akan dapat memberdayakan semua warga Indonesia untuk berkembang menjadi manusia berkualitas, serta mampu dan proaktif menjawab tantangan zaman yang selalu berubah(Alizamar, 2012).

Senada dengan visi pendidikan nasional tersebut, Rencana Strategis Pendidikan Nasional 2005-2010 menyatakan kemauan keras bahwa pada tahun 2025 akan dapat menghasilkan peserta didik sebagai Insan Indonesia Cerdas dan Kompetetif sehingga menghasilkan manusia Indonesia yang cerdas spiritual, cerdas emosional dan sosial, cerdas intelektual dan cerdas kinestetik(Depdiknas, 2010). Cita-cita dan rencana pendidikan tinggi tersebut akan dapat diwujudkan melalui proses pembelajaran dengan memperhatikan peningkatan kualitas untuk pengembangan kebutuhan mahasiswa, perluasan akses pendidikan dengan kesetaraan kesempatan pendidikan bagi semua warga negara serta otonomi pendidikan untuk pengembangan inovasi dan keunggulan yang lebih jauh (Alizamar, 2012; Depdiknas, 2010).

Perwujudan segenap tujuan di atas menghadapi berbagai tantangan yang cukup berarti, seperti orientasi pendidikan yang mengutamakan hasil daripada proses, manajemen pendidikan yang mengutakan kepentingan bisnis daripada nilai-nilai pedagogis, munculnya pemikiran bahwa tindakan mencontek dan plagiarisme adalah hal wajar bagi mahasiswa, serta perhatian yang terlalu besar pada pengembangan kemampuan kognitif mahasiswa dibandingkan dengan nilai-nilai karakter dalam proses pembelajaran(Arjanggi, 2012).Untuk mengantisipasi tantangan tersebut perlu dipersiapkan mahasiswa sebagai generasi pasti akan menghadapi tantangan tersebut melalui mengaktifkan segenap energi mereka melalui pembelajaran.Aktivasi energi belajar mahasiswa menuju arah kegiatan belajar merupakan indikator penting dalam melihat pemenuhan tujuan pembelajaran sehingga muncul berbagai fenomena mahasiswa 
yang sering terlambat menyerahkan tugas, kalau dosen tidak datang memberi kuiah mahasiswa lebih suka duduk mengobrol di kafe atau di tempat lain daripada belajar di perpustakaan atau berdiskusi di kelas, tidak suka bertanya ketika mengikuti kuliah, ketidakmampuan berpikir kritis, pikiran pragmatis mahasiswa yang berkesimpulan bahwa kegiatan mencontek merupakan hal yang lumrah agar bisa lulus dalam suatu matakuliah (Aizikovitsh \& Amit, 2010; Alizamar, 2012; Arjanggi, 2012; Batubara, 2014). Kondisi energi belajar yang redup tersebut lambat laun akan menciptakan kondisi pencapaian prestasi belajar yang tidak optimal bagi mahasiswa.

Selanjutnya tantangan dalam dunia pendidikan adalah pembelajaran yang semata hanya mengutamakan keunggulan individu pada ranah tertentu sehingga menghasilkan prestasi semu. Kondisi ini pada hakikatnya akan menjadikan peserta didik (mahasiswa) yang hanya mengandalkan pengetahuan tanpa bisa diterapkan dalam perilaku, kebiasaan bahkan karakter (Arjanggi, 2012; Prayitno \& Khaidir, 2011). Permasalahan dalam kegiatan pembelajaran akan terasa tidak menyenangkan dengan indikator kurang adanya semangat siswa dalam proses perkuliahan, belajar akan dirasakan sebagai suatu beban yang sulit, terjadinya berbagai kecelakaan dalam pendidikan, kekerasan dalam pendidikan dengan alasan penegakan disiplin, diskriminasi mata pelajaran tertentu, kurang adanya kedekatan antara pendidik dan peserta didik, adanya kondisi pembiaran terhadap potensi peserta didik yang dapat berkembang lebih optimal (Alizamar, 2012; Batubara, 2014; Daharnis, Erlamsyah, Alizamar, \& Afdal, 2011; Prayitno \& Khaidir, 2011).

Kondisi penting yang juga menjadi fokus perhatiandalam proses pendidikan di perguruan tinggi adalah berbagai perubahan global yang terjadi beserta tantangannya. Kemajuan teknologi dan arus globalisasi serta informasi yang sangat pesat menjadi faktor penting yang menciptakan kondisi persaingan baru. Tuntutan dalam menghadapi arus globalisasi tersebut memerlukan adanya kompetensi yang mumpuni dalam hal kemampuan berkomunikasi, kemampuan berpikir jernih serta kritis, kemampuan bertanggungjawab terhadap diri dan lingkungan, serta memiliki kesiapan untuk bekerja (Wibowo, 2014). Permasalahan lain juga juga patut untuk dijadikan sorotan adalah berkenaan dengan pengelolaan pendidikan, berbagai kondisi seperti manajemen pendidikan dengan orientasi bisnis, adanya mismatched antara kompetensi yang dimiliki pendidikan dengan apa yang ia ajarkan, kondisi kekurangan dosen atau pendidik di perguruan tinggi, adanya keinginan kuat untuk berlomba menghasilkan lulusan yang banyak secara kuantitas bukan berorientasi pada kualitas lulusan, serta dukungan rendah dari masyarakat (Prayitno \& Khaidir, 2011). Kondisi tersebut secara nyata akan ikut memberikan pengaruh yang signifikan terhadap proses pendidikan di perguruan tinggi.

Berbagai temuan di lapangan yang merupakan dampak langsung dari permasalahan pendidikan tersebutadalah banyaknya mahasiswa mengalami permasalah dalam belajar. Permasalahan belajar yang dialami mahasiswa secara nasional memiliki rata-rata sebesar 46,67 dan untuk mahasiswa salah satu perguruan tinggi negeri di Kota Padang memiliki rata-rata sebesar 45,74 (Alizamar, 2012). Selain itu apabila dilihat hubungan antara kondisi lingkungan dan kegiatan belajar dengan prestasi belajar mahasiswa yang memiliki kontribusi hanya sebesar $18 \%$ dengan pemaknaan bahwa perilaku dan keterampilan belajar mahasiswa tidak banyak berubah meskipun sudah memiliki status sebagai mahasiswa serta tidak mampu memenuhi berbagai tuntutan dari perguruan tinggi (Alizamar, 2012; Daharnis et al., 2011). Kecenderungan raw input bagi perguruan tinggi yang mengalami permasalahan juga merupakan kendala yang berarti, diantaranya kondisi belum siapnya mahasiswa menghadapi kondisi pembelajaran di perguruan tinggi (Alizamar, 2012; Arjanggi, 2012; Daharnis et al., 2011) dan juga dipengaruhi oleh ketidaksiapan menghadapi berbagai perbedaan individu (baik berupa budaya maupun daya saing) dalam proses pembelajaran (D'Andrea \& Gosling, 2005).

Bila ditelaah lebih lanjut, kondisi permasalahan pendidikan di atas lebih banyak disebabkan oleh adanya kondisi disintegrasi antara karakter dan kecerdasan pada diri mahasiswa. Peningkatan kualitas pendidikan secara menyeluruh akan dapat diwujudkan apabila peserta didik tidak hanya fokus pada pengembangan pengetahuan dan koginitif saja, namun juga perlu ada upaya peningkatan pada ranah nilainilai karakter secara menyeluruh. Aspek indikator karakter yang dimaksud adalah seluruh sifat pribadi yang relatif stabil pada diri individu yang menjadi landasan bagi tampilan perilaku dalam bentuk standar nilai dan norma yang tinggi, dan aspek kecerdasan yang dimaksud adalah seluruh kemampuan untuk memanipulasi segenap unsur-unsur kondisi yang dihadapi untuk bisa sukses mencapai tujuan (Prayitno \& Khaidir, 2011). 
Karakter cerdas yang dimaksud adalah segenap sifat pribadi yang relatif stabil pada diri individu yang menjadi suatu landasan dalam penampilan perilaku dengan standar norma dan nilai yang tinggi diiringi tindakan yang mampu untuk menghadapi berbagai kondisi untuk sukses mencapai tujuan (Prayitno \& Khaidir, 2011). Indikator karakter yang tercermin dalam perilaku individu diantaranya iman dan takwa, sabar, pengendalian diri, disiplin, kerja keras, ulet, bertanggung jawab, jujur, membela kebenaran, sopan santun, taat pada peraturan, demokratis, loyal, sikap kebersamaan, musyawarah, gotongroyong, toleran, tertib, damai, anti kekerasan, hemat dan konsisten. Sedangkan indikator kecerdasan yang mengiringi perilaku berkarakter tersebut yakni aktif, dinamis dan terarah, analitis dan objektif, aspiratif, kreatif dan inovatif, antisipatif, berpikiran terbuka dan maju, serta mencari solusi (Prayitno \& Khaidir, 2011).

Pendidikan karakter-cerdas tersebut akan terlaksana dengan baik salah satunya melalui proses pembelajaran yang memuat nilai-nilai tersebut (Arjanggi, 2012; Prayitno \& Khaidir, 2011). Dengan demikian, rasional pelaksanaan pendidikan karakter-cerdas melalui proses pembelajaran merupakan salah satu stategi yang dirasa tepat untuk diterapkan. Perlu adanya berbagai unsur penting dalam pelaksanaan pembelajaran yang menanamkan nilai-nilai karakter-cerdas tersebut, seperti strategi pembelajaran, pendekatan, maupun materi dari pembelajaran tersebut sehingga isi/konten karakter-cerdas dimaksud benarbenar dapat diterima oleh mahasiswa dalam proses transformasi pembelajaran.

\section{Pembelajaran di Perguruan Tinggi dan Urgensi Pendidikan Karakter-Cerdas.}

Pendidikan merupakan segala upaya dalam rangka memuliakan kemanusiaan manusia dalam seluruh aspek kehidupannya (Prayitno \& Khaidir, 2011; Wibowo, 2014). Oleh karena itu, pendidikan seyogyanyalah berada dalam kaidah-kaidah teori keilmuan dalam bentuk keilmuan pendidikan. Sehingga, suasana belajar dan proses pembelajaran yang merupakan makna penting dalam pendidikan hendaknya dapat terwujud sebagaimana yang seharusnya. Melalui suasana belajar dan proses pembelajaran itulah peserta didik dan pendidik berdinamika dan melakukan interaksi dengan sasaran mencapai tujuan pendidikan yang akan membuahkan hasil pendidikan (Prayitno \& Khaidir, 2011).

Konsep pendidikan tersebut juga mengandung makna bahwa tidak akan ada pendidikan tanpa adanya proses belajar dan suanana pembelajaran, dimana situasi ini juga terjadi pada pendidikan di perguruan tinggi. Berkenaan dengan hal tersebut, pendidikan tinggi mempersiapkan kurikulum pembelajaran yang lebih berorientasi pada pengalaman mahasiswa sesuai dengan okupasi karir, memahami berbagai konsep dan persiapan untuk terjun ke dunia profesional sesuai bidang keilmuannya masing-masing (Billet \& Henderson, 2011).

Suksesnya pendidikan mahasiswa di perguruan tinggi dapat diindikasikan oleh terlaksananya trisukses perguruan tinggi, diantaranya sukses akademik yang dicirikan oleh perolehan indeks prestasi mencukupi, menamatkan studi tepat waktu dan terkuasainya kompetensi utama minimal dalam bentuk teori dan paraktek. Selanjutnya adalah sukses dalam mempersiapkan karir, yakni mahasiswa yang terarah dalam mengembangkan segenap potensi dan memiliki arah karir yang sesuai program studi dengan memahami berbagai aspek berkenaan dengan jenjang karir di masa yang akan datang (prospek karir, masa tunggu dan lain sebagainya). Sukses ketiga adalah sukses dalam sosial-kemasyarakatan, hal ini diindikasikan dengan kemampuan mahasiswa membina hubungan sosial secara luas baik dengan sesama mahasiswa, warga kampus, maupun masyarakat sehingga memberikan sumbangan berarti bagi kesuksesan mahasiswa tersebut (Alizamar, 2012; Prayitno, 2007).

Wujud sukses tersebut akan dapat diperoleh mahasiswa dengan mengaktifkan segenap potensi yang ia miliki, salah satunya melalui proses pembelajaran. Pembelajaran yang dimaksud tidak hanya menekankan pada pengembangan kemampuan kognitif saja namun juga mengembangan karakter dari mahasiswa. Dalma kaitannya dengan pembentukan karakter-cerdas, suatu hal baru yang menjadi perhatian adalah hal-hal yang dapat memperkuat kecerdasan peserta didik dengan standar nilai dan norma yang tinggi terhadap potensi manusia seutuhnya dengan memuat kandungan harkat dan martabat manusia beserta nilai-nilai luhur Pancasila yang mengandung seluruh unsur kehidupan, konten tersebut diintegrasikan dalam materi 
perkuliahan yang menjadi bagian dari kurikulum sesuai bidang studinya. (Prayitno \& Khaidir, 2011; Tim Penyusun, 2011).

Dalam pelaksanaannya, pembelajaran dengan mengintegrasikan nilai-nilai karakter-cerdas dimaksud dapat diselenggarakan dengan dua format utama, yaitu format klasikal dan format nonklasikal(Prayitno \& Khaidir, 2011; Tim Penyusun, 2011). Format klasikal diselenggarakan terhadap sejumlah peserta didik yang dapat juga dikatakan sebagai rombongan belajar, sedangkan format nonklasikal diselenggarakan terhadap sekelompok atau peserta didik secara individual(Prayitno \& Khaidir, 2011).

Pembelajaran di perguruan tinggi dengan mengintegrasikan nilai-nilai karakter-cerdas tersebut memerlukan berbagai pendekatan dan strategi pembelajaran. Hal ini dimaksudkan agar dalam proses pembelajaran terjadi proses metakognitif yang melibatkan pemrosesan informasi, memori, dan pengaruhpengaruh dari konten pembelajaran (Arends, 2001). Penggunaan strategi dan pendekatan yang tepat dalam menanamkan nilai-nilai karakter-cerdas pada proses pembelajaran kepada mahasiswa diharapkan dapat menumbuhkan nilai-nilai dimaksud. Sehingga setelah melalui proses pembelajaran tersebut, mahasiswa diharapkan menjadi lebih kreatif, produktif, memiliki rasa ingin tahu yang tinggi, bertanggungjawab, memiliki kepedulian dan kompetitif dalam era globalisasi (Arjanggi, 2012; Prayitno \& Khaidir, 2011; Wibowo, 2014).

\section{Infusi Nilai-nilai Karakter-Cerdas sebagai Pendekatan dalam Pembelajaran}

Proses pembelajaran yang merupakan aspek penting dalam pendidikan menjadi area yang cukup efektif dalam menanamkan nilai-nilai karakter-cerdas mahasiswa. Kesadaran akan pentingnya integrasi nilainilai karakter-cerdas dalam proses pembelajaran hendaklah dibarengi dengan proses pembelajaran yang secara holistik memiliki nilai-nilai tersebut (Ghufron, 2010). Intervensi nilai-nilai tersebut akan sangat efektif dilakukan dalam proses pembelajaran sehingga proses kontekstualisasi materi dengan nilai karakter mahasiswa yang diharapkan dapat terjadi (Arjanggi, 2012; Ghufron, 2010).

Dalam memberikan intervensi mengenai nilai-nilai karakter-cerdas tersebut, perlu adanya strategi dalam pembelajaran. Hal ini berkaitan dengan kebermaknaan yang akan diperoleh mahasiswa dan dikuasainya sesuatu yang baru sebagai produk belajar (Prayitno \& Khaidir, 2011; Tim Penyusun, 2011). Lebih jauh, strategi tersebut harus secara konkrit dapat meransang unsur-unsur penting dalam dinamika pembelajaran, yakni kemampuan berpikir, merasa, bersikap, bertindak dan bertanggungjawab (BMB3), yang dalam hal ini diberikan sceara transformasional kepada mahasiswa (Prayitno \& Khaidir, 2011). Strategi tersebut hendaknya didahului oleh perencanaan yang matang dari dosen, sehingga nilai-nilai karakter-cerdas yang akan diintegrasikan di dalam proses pembelajaran benar-benar dirasakan oleh mahasiswa.

Strategi pembelajaran tersebut juga memerlukan pendekatan tertentu dalam pelaksanaannya. Pembelajaran dengan menerapkan pendekatan infusi merupakan salah satu cara yang efektif dalam menanamkan konten yang akan disampaikan. Hal ini bertitik tolak pada kemampuan infusi materi yang dapat merangsang kemampuan berpikir dan kontrol dalam proses pembelajaran (Baftim \& Mustapha, 2010), selain itu pembelajaran dengan metode infusi juga akan menciptakan kemampuan berpikir kritis sehingga mahasiswa sebagai sasaran ajar akan diarahkan dalam berpikir secara kontekstual serta mengaitkan materi pembelajaran dengan situasi-situasi nyata yang sedang dihadapi (Aizikovitsh \& Amit, 2010; Baftim \& Mustapha, 2010; Goyakla Apache \& Rizzo, 2005).

Beberapa hal penting yang hendaknya dipahami oleh dosen dalam melakukan infusi nilai-nilai karakter-cerdas melalui proses pembelajaran diantaranya: pertama, berkenaan dengan pembangunan iklim akademik yang memadai. Iklim tersebut tercipta dengan adanya budaya akademik yang kental di perguruan tinggi, hal ini dilakukan melalui beberapa pengembangan, misalnya kedisiplinan dosen dan mahasiswa dalam proses pembelajaran, peningkatan kualitas dosen terutama dalam hal kompetensi dan dapat membangun serta merangsang kemampuan mahasiswa secara optimal (D'Andrea \& Gosling, 2005). Kedua, pendekatan infusi nilai-nilai karakter-cerdas dirasa akan cukup efektif dengan melakukan kontekstualisasi materi melalui halhal yang saling berhubugan (interrelated knowledge). Nilai-nilai karakter-cerdas yang dapat saling berhubungan dengan materi/konten perkuliahan ini hendaknya dapat memuat pemahaman konsep materi (knowing that), mengetahui bagaimana hubungannya (knowing how) dan mengetahui untuk apa materi 
dibahas (knowing for) (Billet \& Henderson, 2011). Dengan demikian mahasiswa tidak hanya mengembangkan kemampuan kognitif berkenaan dengan materi, namun juga kaitannya secara nyata dengan nilai-nilai karakter-cerdas dalam kehidupan sehari-hari.Ketiga, dosen dapat mempersiapkan berbagai topik bahasan yang cukup menarik, aktual dan berkaitan dengan kondisi kehidupan sehari-hari berkaitan dengan materi/konten yang sedang dibahas, kemudian melakukan refleksi terhadap nilai-nilai karakter cerdas (Arends, 2001) materi tersebut juga dapat menjadi ransangan bagi siswa dalam mengembangkan nilai-nilai yang ada pada dirinya (Prayitno \& Khaidir, 2011). Hal ini dimaksudkan agar nilai-nilai dari peristiwa aktual yang terjadi di masyarakat dapat menjadi pembahasan dalam proses pembelajaran, sehingga proses infusi nilai karakter-cerdas dapat dilakukan.

\section{PENUTUP}

Tantangan dalam dunia pendidikan secara signifikan berasal dari kondisi anti karakter-cerdas yang semakin merajalela. Semangat mewujudkan amanat Undang-undang Dasar Tahun 1945 untuk mencerdaskan kehidupan bangsa seperti terjerat dengan kondisi fenomena yang justru sebaliknya. Pembelajaran yang seharusnya bersifat menyeluruh dan menyentuh segenap aspek diri individu hanya dapat mengembangkan pengetahuan tanpa dapat dubah menjadi tingkah laku apalagi karakter (Prayitno \& Khaidir, 2011).

Berbagai fenomena dalam pendidikan tersebut merupakan titik tolak untuk kembali melakukan perbaikan dalam proses pembelajaran sebagai nyawa dari pendidikan. Salah satu upaya nyata yang dapat dilakukan demi mewujudkan cita-cita nasional tersebut adalah menyelenggarakan pendidikan karakter-cerdas bagi mahasiswa (Arjanggi, 2012; Ghufron, 2010; Prayitno \& Khaidir, 2011; Tim Penyusun, 2011; Wibowo, 2014). Proses pembelajaran tersebut dilaksanakan melalui strategi transformatif BMB3 (berfikir, merasa, bersikap, bertindak, dan bertanggungjawab) dengan pendekatan infusi nilai-nilai karakter-cerdas. Strategi dan pendekatan ini pada dasarnya bertujuan untuk meransang kemampuan dan potensi peserta didik dengan memasukkan (infusi) berbagai aspek karakter-cerdas dalam proses pembelajaran. Proses infusi juga dilakukan dengan mengaitkan berbagai kondisi sosial masyarakat yang bersifat aktual dan menarik untuk dibahas serta mengaitkannya dengan materi/konten pembelajaran.

\section{DAFTAR PUSTAKA}

Aizikovitsh, E., \& Amit, M. (2010). Evaluating an infusion approach to the teaching of critical thinking skills through mathematics. Procedia-Social and Behavioral Sciences, 2(2), 3818-3822.

Alizamar. (2012). Model Pendekatan Kelompok dalam Pengembangan Kegiatan Belajar Mahasiswa. (Disertasi, Program Doktor), Universitas Negeri Padang, Padang.

Arends, R. (2001). Learning to Teach (Fifth Edition ed.). Singapore: McGraw Hill.

Arjanggi, R. (2012). PENDIDIKAN KARAKTER TERINTEGRASI DALAM PEMBELAJARAN DI PERGURUAN TINGGI. Prosiding Seminar Nasional Psikologi Islami.

Baftim, S. S. S. A., \& Mustapha, G. (2010). Infusion of thinking skills in english language instructional development at tertiary level. Pertanika Journal of Social Science and Humanities, 18(SPEC. ISSUE), 65-85.

Batubara, J. (2014). Pengembangan Karakter Jujur Melalui Pembiasaan Prosiding International Guidance and Counseling Seminar.

Billet, S., \& Henderson, A. (Eds.). (2011). Developing Learning Professionals (Vol. 7). New York: Springer.

D'Andrea, V., \& Gosling, D. (2005). Improving Teaching and Learning in Higher Education. New York: McGraw Hill.

Daharnis, Erlamsyah, Alizamar, \& Afdal. (2011). Hubungan Aspirasi, Persepsi, Locus of Control, Angkatan dan Status Masuk dengan Kegiatan Belajar Mahasiswa Jurusan Bimbingan dan Konseling FIP UNP. Padang: Universitas Negeri Padang.

Depdiknas. (2010). Rencana Strategis Pendidikan Nasional.

Ghufron, A. (2010). Integrasi nilai-nilai karakter bangsa pada kegiatan pembelajaran. Cakrawala pendidikan, $1(3)$.

Goyakla Apache, R. R., \& Rizzo, T. (2005). Evaluating effectiveness of an infusion learning model on attitudes of physical education majors. Perceptual and Motor Skills, 101(1), 177-186.

Prayitno. (2007). Pengembangan Potensi Mahasiswa. Padang: UNP Press. 
International Counseling Seminar 2015

Padang, $13-14^{\text {th }}$ Maret 2015

Prayitno, \& Khaidir, A. (2011). Model Pendidikan Karakter-Cerdas. Padang: UNP Press.

Tim Penyusun. (2011). Petunjuk Pelaksanaan Pembelajaran Karakter-Cerdas Format Klasikal. Padang: Universitas Negeri Padang.

Undang-undang Republik Indonesia Nomor 12 Tahun 2012. Pendidikan Tinggi.

Wibowo, M. E. (2014). Generasi Muda Berkarakter dalam Membina Keluarga Bebas Narkoba. Prosiding International Guidance and Counseling Seminar. 